(Uniwersytet Jagielloński, Kraków, e-mail: jadwiga.waniakowa@uj.edu.pl)

ORCID: 0000-0002-1651-1572

\title{
GWAROWE NAZWY ROŚLIN JAKO ODBICIE NASTAWIENIA UŻYTKOWNIKÓW GWAR DO PRZYRODY (UJĘCIE HISTORYCZNO-PORÓWNAWCZE)
}

Jak wiadomo, wszelkie nazwy roślin sa motywowane cechami poszczególnych rodzajów i gatunków. Motywacja taka obejmuje zarówno nazwy dawne, jak i współczesne, dotyczy nazw oficjalnych, potocznych oraz gwarowych. Co więcej, mamy $z$ nia do czynienia chyba we wszystkich językach, przynajmniej w językach europejskich. Nazwa rośliny zatem zwykle „wynika” $z$ werbalizacji jej szeroko pojetych cech gatunkowych. Ludzie, którzy kiedyś w przeszłości nadawali i obecnie nadaja nazwy roślinom, zwracali i zwracaja uwage na najbardziej charakterystyczne ich cechy. Były to i sa to cechy, które w poczuciu osób tworzacych nazwy w danej sytuacji nominacyjnej okazywały się i okazuja się najważniejsze. Metodę semantycznej klasyfikacji nazw roślin, opierająca się na cechach typowych dla danego rodzaju lub gatunku, na gruncie polskim już dawno zastosował Eugeniusz Pawłowski [1974, 163-169], a inni przejęli ją i rozbudowali na swój sposób, jak na przykład Ryszard Tokarski [1993, 340-341], który stwierdził, że cechy gatunków roślin, najbardziej istotne dla człowieka, można ująć w trzy ogólne grupy: charakterystyka środowiskowa (w tym również czas kwitnienia - jako najbardziej znaczacy dla rozwoju rośliny - oraz pora zbioru), cechy fizyczne oraz właściwości użytkowe. Tego rodzaju klasyfikacji nazw roślin używano już wcześniej w Europie, przykładem może być monumentalne dzieło Heinricha Marzella, Wörterbuch der deutschen Pflanzennamen [por. Marzell 2000], którego pierwsze wydanie pierwszego tomu ukazało się w roku 1943. Niesłychanie bogaty materiał historyczny i gwarowy jest $\mathrm{w}$ nim uporządkowany w obrębie haseł właśnie według cech gatunków roślin. Na tej podstawie można przekonać się, że w rzeczywistości motywacja semantyczna nazw roślin jest dużo bardziej złożona, ponieważ wymienione przez R. Tokarskiego główne grupy właściwości rozkładaja się na wiele innych, tworzac dość rozbudowana i skomplikowana siatkę [por. np. Dębowiak, Waniakowa 2019, 175-184]. Jednak ogólnie rzecz ujmując, nazwy wywodza się od ich wyglądu, miejsca występowania, właściwości gatunkowych i przeznaczenia roślin [por. Waniakowa 2012, 68]. 
Pewne cechy gatunkowe roślin wywołuja określone skojarzenia, które daja asumpt do tworzenia licznych nazw metaforycznych. Należy zatem mieć na uwadze, że podstawa każdej tego rodzaju metafory jest właściwość danego gatunku, chociaż nie zawsze ten związek jest oczywisty i widoczny na pierwszy rzut oka. Ze względu na dużą liczbę tego typu nazw roślin problem ich metaforyczności był już wielekroć poruszany w literaturze językoznawczej przy różnych okazjach [por. np. Hladká 2000; Waniakowa 2016, 413-425]. Użyte metafory prowadzą do dalszych odniesień, na przykład do legend, w tym legend chrześcijańskich, lub ogólnie do różnych wierzeń związanych $z$ roślinami ze względu na ich właściwości lecznicze, przypisywane im własności magiczne oraz zwyczaje związane $z$ roślinami. Warto zaznaczyć, że nazwy metaforyczne moga być uważane za swego rodzaju nazwy wtórne, ich motywacja semantyczna jest bowiem $\mathrm{w}$ istocie dwuetapowa. Pierwszy etap to dostrzeżenie charakterystycznej cechy danego gatunku rośliny, drugi - to takie przetworzenie tejże cechy, aby na zasadzie podobieństwa do jakiegoś obiektu, dla którego ta cecha jest typowa, nazwa tego obiektu mogła być przeniesiona na tenże gatunek rośliny. Innymi słowy, wytwarza się związek między gatunkiem rośliny a jakimś obiektem. Przy każdym przywołaniu nazwy rośliny, przejętej od danego obiektu, związek ten jest odnawiany [por. Waniakowa 2012, 190].

Badacze polskich gwarowych nazw roślin, na przykład Halina Pelcowa $[2001,100]$, również zauważają, że istotną rolę $\mathrm{w}$ procesie nominacyjnym roślin odgrywa wiara w ich nadzwyczajna (zła lub dobra) moc oraz legendy zwiazane $z$ pewnymi roślinami. Ponadto wchodza tu $\mathrm{w}$ grę liczne odniesienia religijne i przesądy, ważne są także różne konotacje symboliczne. Trzeba tu jednak podkreślić, że tego rodzaju motywacje nie sa nowe i nie dotycza jedynie gwar. Nazwy roślin majace nawiazania religijne sa najczęściej bardzo dawne i występuja w prawie całej Europie. Warto też nadmienić, że większość nazw odwołujących się do legend chrześcijańskich zawiera elementy teonimiczne lub antroponimiczne.

Niezmiernie istotna kwestia przy analizie motywacji semantycznej gwarowych nazw roślin w kontekście wierzeń jest problem tabu. ${ }^{1}$ Pojawia się on zwykle w dwóch sytuacjach: gdy gatunki roślin są uważane za magiczne, to jest rzekomo mające własności nadprzyrodzonego tworzenia dobra (np. właściwości apotropaiczne, moc odstraszania złych duchów itd.) lub zła (np. powodowanie chorób w magiczny sposób) albo gdy sa wysoce szkodliwe, niebezpieczne dla człowieka i moga nawet spowodować jego śmierć. W obydwu wypadkach nazw roślin się nie wymawia. Omija się je, aby nie przywołać „złego” lub aby nie „obrazić” dobroczynnej rośliny niepotrzebnym, daremnym jej przywoływaniem i nie odbierać

1 Zagadnienie to, jako wpływajace w znacznym stopniu na kształt leksyki, jest przedmiotem wielu opracowań językoznawczych, por. np. Tyrpa 2001; Janyšková 2003, 184-186. 
jej tym samym mocy. Im silniejsza jest wiara w siłę oddziaływania roślin, tym większe tabu jest $z$ nimi związane [por. Waniakowa 2012, 190-191]. Co ciekawe, $z$ tabu mamy do czynienia nawet $\mathrm{w}$ polskich nazwach naukowych, które mają długa tradycję, bo biora początek $z$ nazw poświadczonych już w staropolszczyźnie, por. np. tojad mocny, Aconitum firmum $R c h b$. syn. Aconitum napellus $L$. [nazwa tojad występuje u Syreniusza 1613, Knapiusza TPLG 1621-1632, Trotza 1764, Lindego SJP; por. też Spólnik 1990, 49], tojeść pospolita, Lysimachia vulgaris L. (formę tojeść notuje SStp. s.v. [por. też Symb. I 265; Stanko 1472; Spólnik 1990, 49]).

Nie wszystkie nazwy roślin obecne $\mathrm{w}$ gwarach sa autentycznie gwarowe, to jest powstałe na gruncie gwarowym, inaczej - będące wynikiem inwencji użytkowników gwar. Znaczna ich część to nazwy odziedziczone. Można je podzielić na nazwy rodzime, mające początek w staropolszczyźnie lub w okresie prasłowiańskim, dawne kalki i dawne zapożyczenia właściwe. Nazwy te zachowały się w gwarach w pewnej mierze do tej pory. Wśród gwarowych nazw roślin, prócz wyżej wspomnianych nazw autentycznie gwarowych i odziedziczonych, sa także nazwy ogólnopolskie, nowe kalki i nowe zapożyczenia. W tym kontekście, wracajac do motywacji, należy stwierdzić, że niezmiernie ważnym zagadnieniem jest problem jej dawności. Otóż trzeba zdać sobie sprawę, że przy kalkach, zwłaszcza tych starych, motywacja jest właściwie odkrywana na nowo, mianowicie użytkownicy gwar dostrzegają dana cechę gatunkowa poprzez nazwę rośliny, a zatem nazwa nie powstaje jako odbicie cech rośliny. Przy tym oczywiście w wypadku kalk pierwotne obce nazwy umotywowane zostały również poprzez dostrzeżone $\mathrm{w}$ dużo wcześniejszym procesie nominacji cechy gatunkowe. Warto zatem podkreślić, że i w tym wypadku przy nazywaniu roślin najważniejsze okazuja się szeroko pojęte właściwości rośliny. Podobna w istocie, ale jednak nieco inna sytuację obserwujemy $\mathrm{w}$ odniesieniu do starych zapożyczeń. Pierwotne nazwy obce, które zostały zapożyczone do gwar, także były motywowane określonymi, uznanymi kiedyś za ważne, cechami roślin. Potem, już na polskim gruncie gwarowym, doszło do zaniku motywacji, to znaczy przestała ona być przejrzysta. Często prowadziło to do zmian formalnych (fonologicznych i morfologicznych), które doprowadzały do adideacji, a zatem do reinterpretacji semantycznej. W ten sposób nazwa zapożyczona zyskiwała nie tylko nowe brzmienie, ale też i nowe znaczenie. Można więc powiedzieć, że takie adideowane nazwy są w jakimś sensie wtórne (jak wyżej wspomniane nazwy metaforyczne, ale jednak w inny sposób), ponieważ nie wywodzą się bezpośrednio od cech rośliny.

Jak wiadomo, każdy gatunek rośliny ma zwykle kilka cech, które sa dla niego charakterystyczne. Stąd duża liczba nazw jednego gatunku, przy czym część $z$ nich może się odnosić do jednej $z$ cech, ale stanowić inne jej ujęcie formalne. Właściwości roślin są diametralnie różne i tworza niebywale szerokie spektrum możliwych cech. Jak wskazano wyżej, część roślin jest dobroczynna dla ludzi i zwierząt, część zaś jest 
szkodliwa. Przy tym wiele nazw funkcjonuje w gwarach od stuleci, przechowując dawne sady ludzi o roślinach (oczywiście nie zawsze zgodne $z$ rzeczywistościa). Jednakże spora część $z$ nich - i te autentycznie gwarowe, i te zapożyczone, i te odziedziczone - odzwierciedla stosunek ludzi do roślin. Zwracało na to uwage już wielu badaczy, tak europejskich [por. np. Marzell 2000²], jak i krajowych [por. np. Wierzbicka 2009, 415-425]. W nazwach roślin zatem widać, które $z$ nich sa lecznicze, które sa trujące (tu mamy do czynienia $z$ nazwami ostrzegawczymi), które były (lub jeszcze sa) uważane za magiczne (dobre lub złe), a które są obdarzone tak wielka moca (dobra lub złą), że stanowią dobrodziejstwo lub niebezpieczeństwo dla ludzi i zwierzat i $z$ tego względu obejmuje je tabu. W nazwach roślin odbija się oczywiście także ich użyteczność i przeznaczenie. $Z$ drugiej strony - odbija się w nich także negatywny stosunek człowieka, jeśli dane rośliny sa bezużyteczne lub maja irytujące cechy.

Poniżej przytoczono motywacje, w których szczególnie wyraźnie widać stosunek człowieka do świata roślinnego. Podano też stosowne przykłady nazw, które mają różne pochodzenie i tradycje.

Jednymi z najważniejszych dla człowieka cech roślin sa ich właściwości lecznicze, już od starożytności bowiem rośliny służyły ludziom do ratowania zdrowia. W ziołolecznictwie ludowym wyróżnia się trzy bardzo ważne etapy: pozyskiwanie surowca roślinnego, przygotowanie $z$ niego leku oraz sama kuracja. Do każdego $z$ tych etapów odnosiły się szczegółowe przepisy. ${ }^{3}$ Własności lecznicze - jako niezwykle istotne - bardzo często stawały się motywacja nazw. Przykładów takich nazw jest $\mathrm{w}$ gwarach mnóstwo. Zwykle wiążą się $z$ nazwami konkretnych dolegliwości, na które dane gatunki sa pomocne, wskazują na sposób działania bądź świadczą o tym, że gatunek jest niezwykle pomocny w wielu schorzeniach. Do pierwszych należą na przykład nazwy dzięwięćsiłu bezłodygowego, Carlina acaulis L.: kołtunowe ziele, plikowe ziele (rośliny używano przeciw kołtunowi) oraz glistnika jaskółczego ziela, Chelidonium maius L.: brodawnik, ziele od brodawek. Do drugiego rodzaju należą na przykład nazwy babki zwyczajnej, Plantago maior L.: gojace listki, wrzodowe liście, goik, goidura oraz nazwy biedrzeńca mniejszego, Pimpinella saxifraga L.: łamikamień, rozpikamień (stosowano go do rozpuszczania kamieni w pęcherzu moczowym, nazwy te sa kalkami określenia łacińskiego saxifraga). Nazwami świadczącymi o tym, że dany gatunek leczy wiele dolegliwości sa na przykład określenia dzięwięćsiłu bezłodygowego, Carlina acaulis L.: dziewięćsił, dziewięciornik (w dodatku liczba dziewięć

2 Zwraca uwage jego sposób przedstawienia motywacji nazw roślin, który przede wszystkim ukazuje stosunek człowieka do danego gatunku, por. zwracanie uwagi na nazwy wywodzące się od właściwości leczniczych, zastosowania, przeznaczenia itd.

${ }^{3}$ Dokładnie omawia je Adam Paluch [Paluch ZZ 10-26), por. też np. Udziela 1891]. 
była uważana przez Słowian za magiczna, co potwierdzają liczni badacze).

Nie sposób omówić w krótkim tekście każdej z nazw tego rodzaju, zatem poprzestaniemy na dwóch przykładach: ${ }^{4}$

paraliżowe ziele 'pierwiosnek lekarski, Primula veris L., syn.: Primula officinalis (L.) Hill': Ostródz, ${ }^{5} \mathrm{Wr}, \mathrm{Mr}$ [Linde SJP; SWil; Majewski SN]; zestawienie występuje w wielu zielnikach i słownikach języka polskiego: notuje je J. Rostafiński już z czasów średniowiecza [Symb. I 265], potem Falimirz 1534, Spiczyński 1542, Siennik 1568, Marcin z Urzędowa 1595, Syreniusz 1613, Knapiusz TPLG 1621-1632, Guldenius 1641, Haur 1730 i Trotz 1764 [Spólnik 1990, 36]; por. stczes. dnavá bylina [Machek 1954, 172], czes. gw. bylina dnová, bylina mrtvičná, bylina šlakovní, bylina šlakova [Kosík 1941, 93; Rystonová 2007], słow. gw. dnava zelina, mŕtvičná zelin(k) a [Buffa 1972, 386-387], por. ros. gw. камчужная [Annenkov 1878], gdzie ros. камчуг m. lub камчуга f. "роdagra, paraliż'; por. też chorw. gw. trava od drhtanja [Šugar HBI]. Nazwy o znaczeniu 'paraliżowe ziele' wiąża się $z$ własnościami leczniczymi rośliny, jak można przeczytać w herbarium Tabernaemontanusa [1588]: „Wegen seiner großen Krafft zum Gegicht” [Marzell 2000 III szp. 1071]; por. też śrłac. herba paralisis, herba paralysis, herba paralitica [Symb. I 265, Marzell 2000 III szp. 1053]. Warto także przytoczyć nazwy pierwiosnka $z$ innych języków: niem. Schlagkraut, Gichtkraut [1591], ang. herb paralysy [1526], fr. herbe de paralysie [1517]. $Z$ niniejszego przeglądu nasuwają się dwa główne wnioski: po pierwsze, zarówno nazwa polska, jak i wszystkie inne sa kalkami nazw łacińskich [Marzell 2000 III szp. 1071, por. też Spólnik 1990, 109], po drugie, nazwy pierwiosnka o znaczeniu 'paraliżowe ziele', należą do wędrujących kalk [por. Waniakowa 2012, 184-185].

brzuszkowiec 'tatarak zwyczajny, Acorus calamus L.': koziel [SGP]; nazwa należy do adideowanych. Stanowi jedna $z$ form, w których adideacja jest najwyraźniejsza. Inna to brzuszkworc: rac, głub [SGP]; por. stczes. prustvorc, prustvorec, czes. gw. brustvorec, bruškvorec, pruškvorec, proškvorec i inne [Čouka 1929; Kosík 1941; Machek 1954, 300], słow. gw. pruškvorec, puškvorec [Buffa 1972], łuż. bróstwonc, bróstwon [Radyserb-Wjela 1909].

Nazwy, jak wskazuje ich zasięg geograficzny w gwarach polskich, sa zapożyczeniami $z$ czeskiego. Tam zaś znalazły się jako pożyczki $z$ niemieckiego, por. niem. gw. Brustwurz, pośw. 1574 [por. Marzell 2000 I szp. 112]. Nastapiło tu skojarzenie $z$ brzuszkiem na zasadzie pewnego

4 Omówienie przykładów, zawartych w niniejszym tekście, jest zaczerpnięte $z$ książki Polskie gwarowe nazwy dziko rosnacych roślin zielnych na tle słowiańskim. Zagadnienia ogólne mojego autorstwa. W niektórych wypadkach dokumentacja i komentarze zostały rozszerzone.

5 Skróty nazw geograficznych (krain, powiatów itp.) za SGP. 
podobieństwa brzmieniowego. W źródłach gwarowych pojawia się poza tym informacja, że roślina służyła jako lek w dolegliwościach układu pokarmowego i rzeczywiście tatarak, jako środek aromatyczny, gorzki, ma zastosowanie przy niedostatecznym wydzielaniu soku żołądkowego i przy zmniejszonym łaknieniu [por. PZZ 170]. Zatem zaleca się go w schorzeniach przewodu pokarmowego, takich jak nieżyt żołądka i jelit. Służy też dobrze w chorobach $z$ występująca goraczka, jak grypa i zapalenie oskrzeli, a także jako środek przeciw kaszlowi [por. ZL 112]. Zastosowanie tataraku jako leku w dolegliwościach układu oddechowego jest odzwierciedlone właśnie w nazwie niemieckiej, skąd wywodzą się formy słowiańskie. Inna polska gwarowa nazwa tataraku, pochodzaca $z$ tego samego etymonu, to brzuszkocz: głub [SGP].

W kulturze ludowej głęboko wierzono w moc magicznego działania roślin. Stosowano wszak nie tylko kuracje roślinne, odbywające się zwykle według skomplikowanych i tajemniczych rytuałów [więcej o tym np. Paluch ZZ 17-26, por. też SZ], ale także używano roślin do praktyk „odczyniania uroków” oraz oczywiście do „zadawania uroków”. Wierzono, że niektóre rośliny, dzięki swojej tajemniczej potężnej mocy, moga chronić człowieka nie tylko przed chorobami, ale także przed wszelkim złem (na przykład przed uderzeniem pioruna). $Z$ drugiej strony, uważano, że moga one sprowadzać zło w różnej postaci (na przykład powodować kłótnie $\mathrm{w}$ rodzinie). Ta wiara $\mathrm{w}$ magiczną moc roślin odbija się w nazwach roślin jako jedna $z$ istotniejszych motywacji nominacyjnych. Przykładów tego rodzaju nazw jest całkiem dużo w gwarach polskich, por. nazwy widłaka goździstego, Lycopodium clavatum L.: swarnababa, swarnik, swarzybaba (jako ziele powodujące kłótnie). Przykładami niech będa tu nazwy przywrotnika pasterskiego, Alchemilla pastoralis Bus. i widłaka goździstego, Lycopodium clavatum $L^{6}{ }^{6}$

grzmotek 'przywrotnik pasterski, Alchemilla pastoralis Bus.': ok. Częstochowy, ok. Międzyrzeca Podlaskiego, sok-podl, radz-podl, raw-maz, ostroł, łow, iłż [SSSL; Weryho 1888; K II 141-142; SGP]; nazwa wiąże się $z$ pradawnym ludowym przekonaniem, że ziele przywrotnika chroni przed uderzeniami piorunów, jak świadczą liczne cytaty ze źródeł gwarowych, np.: „przed burza trzeba wianek powiesić w oknie albo w ogień wrzucić". Źródła podają też, że przywrotnik święci się w celu odpędzania chmur. $Z$ rzekomymi właściwościami ochronnymi przywrotnika wiąże się także podobna nazwa przywrotnika, mianowicie grzmotnik: kiel, lub, ok. Międzyrzeca Podlaskiego, radz-podl, ok. Pińczowa, Ryp i Lip, wiel [SZ;

6 Tematyka związana $z$ magicznością roślin jest bardzo szeroka, a literatura jej poświęcona jest ogromna, ponieważ roślin, które uważano za magiczne, jest wyjątkowo dużo [por. np. Spólnik 1983, 165-171]. W wielu kulturach jedna z ważniejszych roślin uważanych za magiczne była mandragora, a na obszarach, gdzie nie rosła, zastępowano ja innymi roślinami [por. Waniakowa 2007, 161-173]. 
SSSL; PZZ; Pelcowa NR; K II 141; SGP]. Przywrotnik uważano zatem za roślinę chroniaca człowieka przed żywiołami.

babimór (babimor) 'widłak goździsty, Lycopodium clavatum L.': ciesz, krak, przem, lub, chłm, kras [SGP; FF 14; SSSL; PZZ; RZ; PZL; USK; SWil; Majewski SN; K VI 125; Pelcowa SGL V 56; SSSL Zioła 421]; według wierzeń ludowych pędy widłaka zawieszone pod sufitem w sypialni w dzień Bożego Ciała miały się przeciwstawiać siłom nieczystym oraz chroniły przed marami nocnymi. Źródła gwarowe mówią o stosowaniu rośliny zwłaszcza przeciw czarownicom. Aby ochronić przed nimi bydło, zawieszano wiązki widłaka na drzwiach obór. Prawdopodobnie stąd wywodzi się nazwa gatunku. ${ }^{7}$ Jest ona bogato poświadczona w historii języka polskiego: postać babimor poświadcza J. Rostafiński z rękopisów sredniowiecznych [Symb. I 102], potem nazwa jako < babimur> występuje u Siennika 1568 i Guldeniusa 1641, postać babi mur podaje Syreniusz 1613, a za nim Knapiusz TPLG 1621-1632 i Trotz 1764 [Spólnik 1990, 51]; pod wpływem polskim brus. gw. бабін мур [Kiselevskij 1967; Pastusiak 2007, 329].

Wydaje się, że tę motywacje mają też inne gwarowe nazwy widłaka goździstego, mianowicie: morzybab (młorzebob, morzybáb, morzybób), morzybaba: Kasz, mal, szt; kart. [SGP; FF 14; RZ; SSSL; PZZ; USK; Paluch ZZ; K III 185; SSSL Zioła 421]; nazwa notowana jest w staropolszczyźnie: J. Rostafiński ze słowniczków średniowiecznych podaje postać morzybab [Symb. I 102], także Stanko 1472 notuje < morzi bab> [Symb. I 102; Spólnik 1990, 51], złożenie to jest także poświadczone w formie mo$r z y b a b$ przez Helwinga $z$ Prus Książęcych z XVIII w. [Helwing Prusy 20], ale jako nazwa widłaka wrońca, Lycopodium selago L.; podobnie babski ciag: ciesz [SGP]; kulibaba: n-tar, kras, lub [RZ; SSSL; SGRT; USK; Paluch ZZ; Pastusiak 2007; Majewski SN; K IV 45; K II 519, VI 10].

Przypisywane magiczne właściwości ochronne uwidaczniaja się także w innych gwarowych nazwach widłaka, por. pas św. Jana: lub, Ostródz, Wr [FF 14; PZZ; PZL; Linde SJP; SWil; Majewski SN; SSSL Zioła 420]; nazwa dobrze poświadczona w historii języka polskiego: występuje u Siennika 1568, Syreniusza 1613, Knapiusza TPLG 1621-1632, Guldeniusa 1641 i Trotza 1764 [por. Spólnik 1990, 51], zob. też SP XVI s.v. pas. Nazwa ma zwiazek $z$ ludowymi wierzeniami, że opasanie się pędami rośliny przynosi szczęście oraz chroni od złego [Spólnik 1990, 114; Pastusiak 2007, 328]. Potwierdza to V. Machek [1954, 27-28] w swojej monografii. Nazwa jest zreszta notowana w języku czeskim, por. czes. gw. pás suatého Jana [Kosík 1941; Rystonová 2007]; por. też inne podobne polskie nazwy gwarowe widłaka goździstego: pasek św. Jana: kras, lub; kart. [SGP; SSSL; Pastusiak 2007; Majewski SN; K II 519, IV 45, VI 103] i świętojański pas: n-tar [Orawa] kart. [SGP]; ta ostatnia nazwa jest

7 Warto dodać, że roślina jest trująca, ponieważ jej pędy zawieraja szkodliwe alkaloidy [Podbielkowski, Sudnik-Wójcikowska 2003, 506]. 
także notowana w języku słowackim, por. słow. svätojánský pás [Buffa 1972, 341]. Należy podkreślić, że trzy ostatnie nazwy widłaka zwiazane są również $z$ wyglądem rośliny, która ma długie wijące się pędy [por. Podbielkowski, Sudnik-Wójcikowska 2003, 505]. Nazwy te sa najprawdopodobniej kalkami z niemieckiego, jak już zauważyła w swym artykule Maria Karpluk [1988, 152], por. niem. S. Johannes Gürtel [pośw. 1591], Johannesgürtel i inne liczne formy [Marzell 2000 II szp. 1478]. Wiara w magiczność widłaka goździstego odzwierciedlona jest jeszcze w innej gwarowej nazwie, która świadczy, że roślina ta, jako mająca wyjątkowo wielka moc czarodziejska, była objęta tabu. Nazwa ta jest nietota: Mp pd [MSGP; SSSL; USK; SSSL Zioła 421]. Poświadcza ja już Stanko 1472, następnie Syreniusz 1613 [Spólnik 1990, 51]. Obecna jest także w innych językach słowiańskich, por. czes., słow. gw. netáta, netata [Machek 1954, 27; Rystonová 2007; Buffa 1972], ukr. gw. nytota [Makowiecki 1936, 220]. Jest to złożenie *nie-to-ta [Otrębski 1966, 101], bo - jak pisze Aleksander Brückner [SEJP 362] - „roślin czarodziejskich nie nazywa się po imieniu, omawia się je przez „to jest” lub „to nie jest”. Potwierdzaja to również inni badacze:

\begin{abstract}
Mianem „nietota” określano niegdyś dla niepoznaki wszystkie czarodziejskie rośliny. Chronić to miało nadprzyrodzone moce ziół przed zakusami złych duchów. A stworów tych w ubiegłych wiekach było dziesiatki (...). Dopiero znajomość nazwy dawała im pełną moc nad ziołami. Dlatego też nazwy roślin obdarzonych tajemnymi siłami trzymano w największej tajemnicy. Nigdy nie mówiono o nich publicznie. Nigdy głośno nie wymawiano ich nazw. Starano się nawet zwieść złe duchy, nazywając czarodziejskie rośliny nietotami, co oznaczało, że dana roślina, właśnie zrywana czy suszona - to nie ta, która słynie w okolicy z nadprzyrodzonych właściwości [Jabłońska 1965, 84],
\end{abstract}

por. też Janyšková 2003, $184 .^{8}$ Sądzę, że takimiż nazwami widłaka, związanymi $z$ tabu, są także nicpotem: ok. Wołkowyska [Bruś] [Pastusiak 2007] oraz nicponim [SSSL Zioła 421].

Jak powszechnie wiadomo, część roślin jest szkodliwa (na przykład odurzajacca, halucynogenna), wręcz trujacca, dla ludzi i zwierząt. W gwarowych nazwach takich gatunków ich szkodliwość jest odzwierciedlona bardzo często. Nazwy tego typu można określić jako ostrzegawcze, por. np. szalej, szaleniec, śpiace ziele - wszystkie odnoszą się do bielunia dziędzierzawy, Datura stramonium L. Przykładem moga być tu także nazwy kakolu polnego, Agrostemma githago L. i tojadu mocnego, Aconitum firmum (Rchb.) Neilr., syn. Aconitum napellus L.:

diabelskie kwiaty 'kakol polny, Agrostemma githago L.': lub [Pelcowa NR]; roślina jest silnie trujacca zarówno dla ludzi, jak i dla zwierząt [por. np. Podbielkowski, Sudnik-Wójcikowska 2003, 191]. Nazwa jest metaforyczna, pełni rolę ostrzegawczą. Pewną rolę może także od-

8 Inaczej A. Bańkowski [ESJP] s.v. nietota, który wiąże tę nazwę z rum. netoată 'niecała'. 
grywać tu tabu (ponieważ mamy do czynienia właściwie $z$ omówieniem, a nie konkretna nazwa), poza tym ewangeliczna przypowieść o kąkolu [Mt. 13, 24-30], gdzie chwast-kakol, ${ }^{9}$ jako symbol zła i grzechu, przeznaczony jest na koniec, po żniwach, do spalenia. Na tej samej zasadzie funkcjonuja także inne polskie gwarowe zestawienia określające kąkol, mianowicie roślina diabelska [USK] i diabelskie ziele: hrub [Pelcowa SGL V 124].

mordecznik 'tojad mocny, Aconitum firmum (Rchb.) Neilr., syn. Aconitum napellus L.' [Majewski SN]; roślina ma silne właściwości trujące, może nawet spowodować śmierć, i to stało się podstawa motywacyjną wielu jej nazw pochodnych etymologicznie od mordować, por. także: morderz [Majewski SN]; zapis <mordesz> [sic!] widnieje u Syreniusza 1613 [Spólnik 1990, 49]; morderznik [Majewski SN]; mordownik: n-tar, krak, Ostródz, Wr, Mr, ok. Poznania [SWil; Majewski SN; SSSL Zioła 414]; formacja pojawia się u Syreniusza 1613, Knapiusza TPLG 1621-1632 i Trotza 1764 [Spólnik 1990, 49]; por. też czes. gw. mordovník [Kosík 1941; Machek 1954, 47; Rystonová 2007], słow. mordouník [Buffa 1972], ros. gw. моримордъ [Annenkov 1878], por. też niem. gw. Totenblume [Marzell 2000 I szp. 106]. Inna nazwa tojadu, także nawiązująca do jego własności trujących, jest omieg (omiak, omiog, omieg, omiag, omiek, łomiak, ułomiak): n-tar, Ostródz, Wr, Mr [SSSL; SGRT; Gustawicz 1882; Majewski SN; K III 76, 442; USK; Paluch ZZ]; formy omieg i omięg poświadcza J. Rostafiński z rękopisów średniowiecznych [Symb. I 164, por. też SStp. s.v.], notuje ją też SP XVI (s.v.), u Syreniusza 1613 znajdujemy zestawienie psi omieg [Spólnik 1990, 49], podaja ją także Knapiusz TPLG 1621-1632 i Linde SJP; por. też stczes. oměj, voměj [Machek 1954, 45], czes. gw. omej, vomèj, vomen, vomin [Kosík 1941; Rystonová 2007], słow. gw. omej, omèj, vomej, omich [Buffa 1972], ros. gw. oмezъ [Annenkov 1878], ukr. gw. om'ak [Makowiecki 1936], słoweń. gw. omej [Karlin 1964]. Według J. Rostafińskiego [Symb. I 164-165] „omieg znaczy po polsku truciznę". Jako potwierdzenie swojego poglądu podaje uwage Marcina $z$ Urzędowa [1595]: „a to ma w sobie omiag”. Wariantem słowotwórczym nazwy jest omiega (omiaga, łomiaga): n-tar [SGRT]; por. czes. omega [Rystonová 2007]. V. Machek [1954, 46] łączy czes. oměj i pol. omieg, omiag $z$ *oměždžiti, a to $z$ *mězga. Według A. Bańkowskiego [ESJP s.v. omieg] jest to „sztucznie rozpowszechniony termin herbarski”, a jego forma staropolska wywodzi się z błędnego odczytania postaci staroczeskich, gdzie litera $<g>$ oznacza [j]. Sama zaś forma czeska została, jak twierdzi A. Bańkowski, przejęta $z$ wołoskiego dialektu wędrownych owczarzy górskich. Najbardziej jednak przekonująca jest etymologia M. Vasmera, który wiąże psł. *oměgr z czasownikiem migat' (< psł. *migati 'migać, mrugać', por. lit. miegóti 'spać', mìgti 'zasypiać', Boryś SEJP s.v. migać) z powodu odurzającego działania rośliny [por.

9 W nowszych tłumaczeniach Biblii kakol został zastapiony przez chwast. 
Vasmer ES III 138-139]. W języku rosyjskim nazwa odnosi się także do 'trującego, gorzkiego napoju' [por. też Spólnik 1990, 73]. Należy zauważyć, że w ESSJ brak hasła oměgr [Waniakowa 2012, 166]. Podobnie do silnych właściwości trujących tojadu nawiazuje nazwa piekielne ziele [SWil; Majewski SN]; zestawienie to poświadczone jest u Syreniusza 1613 [Spólnik 1990, 49, 115], por. niem. Teufelswurz [pośw. 1673] i niem. gw. Teufelskraut [Marzell 2000 I szp. 106]. Roślin takich jak tojad unikano, bano się ich panicznie, $z$ obawy przed ich wielka zła moca nie wymawiano ich nazw, stosujac $\mathrm{w}$ razie potrzeby omówienia. O tabu świadczy także bylina $z$ ok. Grodna [Bruś] [Szcześniak 2008] jako nazwa tojadu, por. brus. gw. bylina [Pastusiak 2007]. Etymologicznie bylina to 'roślina' od psł. *bylo 'ziele, trawa'.

Podstawą nominacyjna nazw roślin jest także ich użyteczność bądź przeznaczenie. To również często spotykana motywacja, bo człowiek, otoczony na co dzień roślinami, starał się od dawna wykorzystać ich właściwości. $Z$ uwagi na brak miejsca posłużmy się jedynie dwoma przykładami tego rodzaju:

śmietannik 'dziewanna wielkokwiatowa, Verbascum thapsiforme Schrad. syn.: Verbascum densiflorum Bertol.' lub 'dziewanna drobnokwiatowa, Verbascum thapsus L.', lub 'dziewanna kutnerowata, Verbascum phlomoides L.' [SSSL; kart. SGP]; według licznych źródeł gwarowych dziewanna, podobnie jak inne rośliny, np. krwawnik pospolity, Achillea millefolium L., służyła jako pasza dla krów, aby mleko było lepsze, czyli bardziej tłuste, żeby powstawała $z$ niego lepsza śmietana.

parzydto 'rzepik pospolity, Agrimonia eupatoria L.': lub [Poprzęcki 1990; K IV 44; SWil; SW]; forma poświadczona przez J. Rostafińskiego ze średniowiecznych słowniczków [Symb. I 197]; por. ukr. gw. paryło [Makowiecki 1936, 15], ukr. gw. парило, ros. gw. nарыло [Annenkov 1878], por. też ros. gw. cyдonapъ, cyдonopъ [Annenkov 1878], gdzie ros. wsp. nocyda 'naczynia'. J. Rostafiński [Symb. I 197] uważa, że nazwa odzwierciedla przeznaczenie rośliny, bowiem służyła ona do wyparzania garnków. W ten sposób motywację tego rodzaju nazw rzepiku ujmował też wcześniej N.I. Annenkov [1878, 16].

Część roślin nie jest przydatna w gospodarstwie, nie nadaje się na paszę, nie jest więc potrzebna ludziom ani zwierzętom. Co więcej, wiele roślin ma przykre właściwości, nawet irytujące dla użytkowników gwar. W zwiazku $z$ tym ich nastawienie do takich roślin jest negatywne, co naturalnie znajduje odbicie w nazwach. Oto typowy przykład:

dziad (zwykle w pl.) 'łopian większy, Arctium lappa L., syn.: Lappa maior Gaertn., Lappa officinalis All.' lub 'łopian mniejszy, Arctium minus Bernh.', lub 'łopian pajęczynowaty, Arctium tomentosum Mill.': łęcz, kiel, kroś, hrub, bił, Kasz [S VII 60; SGP; SZ; SSSL; PZL; Kurek 2004; ZDK; Pelcowa SGL V 133]; por. brus. gw. dz'èt [Pastusiak 2007], ros. gw. дёдкu [Annenkov 1878]. Nazwa jest aluzją do czepliwości koszyczków kwiatowych rośliny, które sa okryte haczykowatymi łuskami, wskutek czego 
kwiatostany łatwo się przyczepiają do ubrań, sierści zwierząt itd. [por. np. PZZ 120]. Mamy tu do czynienia $z$ daleko posunięta metafora, bo, po pierwsze, nazwa rośliny jest motywowana właściwościami kwiatostanów i tylko one brane sa pod uwage (pars pro toto), po drugie, czepliwość ich jest porównana do natręctwa żebraka. Tę samą motywację widzimy $\mathrm{w}$ innej nazwie łopianu, mianowicie dziadownik 'lopian większy, Arctium lappa L., syn.: Lappa maior Gaertn., Lappa officinalis All.' lub 'łopian mniejszy, Arctium minus Bernh.' [USK; SSSL; Paluch ZZ]; por. ukr. gw. d'idovnyk, didovnik, де̌довникъ ${ }^{10}$ [Makowiecki 1936, 199, 200; Annenkov 1878], ukr. gw. дїовник [Pastusiak 2007], brus. gw. дзядовникь [Annenkov 1878; Kiselevskij 1967]. W tym wypadku jest to derywat, ale mechanizm nominacyjny jest identyczny. Obie nazwy łopianu opierajace się na stereotypie dziada-żebraka, którego wyróżniająca cechą jest między innymi natręctwo, sa deprecjatywne.

Powyższy przegląd motywacji nazw roślin, w których szczególnie wyraźnie odbija się stosunek człowieka do świata roślinnego, to jedynie zarys ogromnej problematyki. Jest oczywiste, że gatunki, które wyjątkowo są ludziom potrzebne ze względu na właściwości, zyskiwały nazwy o pozytywnym wydźwięku, a te, które sa nieprzydatne i szkodliwe, otrzymywały nazwy pejoratywne. W części nazw, które odnosza się do roślin uważanych za magiczne, potężne w swojej mocy, przejawia się tabu. Warto podkreślić, że wiele nazw, które uważane sa za gwarowe, ma $\mathrm{w}$ istocie rodowód bardzo dawny, który bynajmniej nie jest gwarowy. Sporą część stanowią nazwy rodzime, ale dużo wśród nich także zapożyczeń i kalk. Stąd w polskich gwarowych nazwach roślin mamy do czynienia $z$ nastawieniem do świata roślinnego nie tyle użytkowników gwar, ile ludzi jako zbiorowości, także w znaczeniu historycznokulturowym. Należy o tym pamiętać, gdy rozpatruje się nazwy roślin w gwarach.

\section{Bibliografia}

N.I. Annenkov, 1878, Ботанический словарь..., Sanktpeterburg.

Bańkowski ESJP - A. Bańkowski, 2000, Etymologiczny słownik języka polskiego, t. I-II $(A-P)$, Warszawa.

Boryś SEJP - W. Boryś, 2005, Słownik etymologiczny języka polskiego, Kraków. Brückner SEJP - A. Brückner, 1974, Słownik etymologiczny języka polskiego, wyd. III, Warszawa.

F. Buffa, 1972, Vznik a vývin slovenskej botanickej nomenklatúry. K histórii slovenského odborného slovníka, Bratislava.

F. Čouka, 1929, Lidové názvy rostlin z Moravy, „Časopis Vlasteneckého spolku musejního v Olomouci“ ročn. XLI-XLII, s. 122-124.

10 Pisownia nieco zmodyfikowana $\mathrm{z}$ powodu braku właściwych znaków. 
P. Dębowiak, J. Waniakowa, 2019, Semantic Motivation of Plant Names as Part of their Etymology [w:] A. Villalva, G. Williams (eds.), The Landscape of Lexicography, Lisboa, s. 173-200.

ESSJ - О.Н. Трубачев (ред.), 1974 і n., Этимологический словарь славянских языков. Праславянский лексический фонд, Moskva.

S. Falimirz, 1534, O ziołach i mocy jich, Kraków.

FF - F. Czyżewski, D. Urban (red.), 2006, Flora i fitonimy na pograniczu polsko-ukraińskim, Lublin.

P. Guldenius, 1641, Onomasticum trilingue latino-germano-polonicum, Królewiec.

B. Gustawicz, 1882, Podania, przesady, gadki i nazwy ludowe w dziedzinie przyrody, cz. 2: Rośliny, „Zbiór Wiadomości do Antropologii Krajowéj”, t. VI, Kraków, s. 201-321.

J.K. Haur, 1730, Wybór ekonomii ziemiańskiej, politycznej, gospodarskiej, Warszawa.

Helwing Prusy - Prowincyonalne, polskie nazwy roślin XVIII w., z Prus Ksiażęcych głównie z rękopisu Andrzeja Helwinga, opr. J. Rostafiński, osobne odbicie z Rozpraw Wydziału Filologicznego Akademii Umiejętności, t. XL, Kraków 1904.

Z. Hladká, 2000, Přenesená pojmenování rostlin v českých dialektech. $K$ sémantickému tvořeni lexikálnich jednotek $v$ nár̆ečich, Brno.

K. Jabłońska, 1965, Czarodziejski zielnik, Warszawa.

I. Janyšková, 2003, K úloze tabu v etymologii, „Studia etymologica Brunensia”, t. 2, red. I. Janyšková, H. Karlíková, s. 179-189.

K - J. Karłowicz, 1900-1911, Słownik gwar polskich, t. I-VI, Kraków.

M. Karlin, 1964, Slovenska imena naših zdravilnih rastlin, Ljubljana.

M. Karpluk, 1988, Kulturowo-antroponimiczne elementy $w$ staropolskich nazwach ziót, [w:] K. Zierhoffer (red.), V Ogólnopolska Konferencja Onomastyczna, Poznañ 3-5 września, Ksiega referatów, Uniwersytet im. A. Mickiewicza w Poznaniu, seria: Filologia polska nr 34, Poznań, s. 147-156.

kart. SGP - kartoteka Słownika gwar polskich, opr. przez Pracownię Dialektologii Polskiej (dawniej: Zakład Dialektologii Polskiej) Instytutu Języka Polskiego PAN w Krakowie.

A.I. Kiselevskij, 1967, Аатино-русско-белорусский ботанический словарь, Minsk.

Knapiusz TPLG 1621-1632 - G. Knapiusz, Thesaurus polono-latino-graecus in tres tomos divisus, t. I-III, Cracoviae 1621-1632.

V. Kosík, 1941, Slovník lidových názvů rostlin, Praha.

H. Kurek, 2004, Językowo-kulturowy obraz wsi podkarpackiej wpisany w nazwy roślin [w:] H. Kurek, J. Labocha, Studia linguistica Danutae Wesołowska oblata, Kraków, s. 129-156.

Linde SJP - S.B. Linde, 1807-1814, Słownik języka polskiego, t. I-VI, Warszawa. V. Machek, 1954, Česká a slovenská jména rostlin, Praha.

Majewski SN - E. Majewski, 1889-1898, Słownik nazwisk zoologicznych i botanicznych polskich..., t. I-II, Warszawa.

S. Makowiecki, 1936, Słownik botaniczny łacińsko-małoruski, Kraków.

Marcin z Urzędowa, 1595, Herbarz polski..., Kraków.

H. Marzell, 2000, Wörterbuch der deutschen Pflanzennamen, t. I-V, Fotomechanischer Nachdruck der Erstausgabe 1943-1958, Köln.

MSGP - J. Wronicz (red.), 2009, Mały słownik gwar polskich, Kraków. 
J. Otrębski, 1966, Z dziejów wyrazów polskich, „Język Polski” XLVI, z. 2, s. 94-101.

Paluch ZZ - A. Paluch, 1989, Zerwij ziele z dziewięciu miedz. Ziołolecznictwo ludowe $w$ Polsce $w$ XIX i na poczatku XX wieku, Wrocław.

K. Pastusiak, 2007, Pogranicze polsko-białorusko-ukrainskie w świetle danych językowych $i$ etnograficznych na podstawie nazw roślin, Warszawa.

E. Pawłowski, 1974, Polskie nazwy roślin (Próba klasyfikacji semantycznej) [w:] J. Kuryłowicz (red.), Studia indoeuropejskie, Prace Komisji Językoznawstwa, t. 37, Wrocław etc., s. 163-169.

H. Pelcowa, 2001, Interferencje leksykalne w gwarach Lubelszczyzny, Lublin.

Pelcowa NR - H. Pelcowa, 2001, Nazwy roślin w świadomości językowej ludności wiejskiej [w:] A. Dąbrowska, I. Kamińska-Szmaj (red.), Język a Kultura, t. 16: Świat roślin w języku i kulturze, Wrocław, s. 99-116.

Pelcowa SGL V - H. Pelcowa, 2017, Słownik gwar Lubelszczyzny, t. V: Świat roślin, Lublin.

Z. Podbielkowski, B. Sudnik-Wójcikowska, 2003, Słownik roślin użytkowych, wyd. VII poprawione i uzupełnione, Warszawa.

W. Poprzęcki, 1990, Ziołolecznictwo, Warszawa.

PZL - E. Kuźniewski, J. Augustyn-Puziewicz, 1986, Przewodnik ziołolecznictwa ludowego, wyd. II uzup., Warszawa-Wrocław.

PZZ - J. Kwaśniewska, J. Skulimowski, H. Tumiłowicz, 1956, Poradnik zbieracza ziół, Warszawa.

J. Radyserb-Wjela, 1909, Serbske rostlinske mjena $w$ dwěmaj dźělomaj a sedmjoch stawach po abejcejskim rjedźe. Čestny pomnik za serbskeho prrirodospytnika njeboh Michała Rostoka zestajał njeboh Jan Radyserb-Wjela, zrjadował a za ćišć přihotował Matej Urban, Budyšin.

I. Rystonová, 2007, Prưvodce lidovými názvy rostlin i jiných léčivých prírodnin a jejich produktů, Praha.

RZ - H. Grochola-Szczepanek, 2002, Rzeczowniki złożone w gwarach polskich, Kraków.

S - B. Sychta, 1967-1976, Słownik gwar kaszubskich na tle kultury ludowej, t. I-VII, Wrocław.

SGP - M. Karaś, S. Urbańczyk, J. Reichan, J. Okoniowa, B. Grabka, R. Kucharzyk (red.), 1979 i n., Słownik gwar polskich, opr. przez Pracownię Dialektologii Polskiej (dawniej: Zakład Dialektologii Polskiej) Instytutu Języka Polskiego PAN w Krakowie, Wrocław-Kraków etc.

SGRT - Z. Radwańska-Paryska, 1992, Słownik gwarowy góralskich nazw roślin $z$ Tatr i Podtatrza, Zakopane.

M. Siennik, 1568, Herbarz, to iest zioł tutecznych, postronnych i zamorskich opisanie..., Kraków.

SPXVI - M.R. Mayenowa, F. Pepłowski, K. Mrowcewicz, 1966 i n., Słownik polszczyzny XVI wieku, Wrocław etc.

H. Spiczyński, 1542, O ziołach tutecznych i zamorskich i mocy ich, Kraków.

A. Spólnik, 1983, Z czarodziejskiego słownika roślin polskich: nasięźrzał (Ophioglossum vulgatum L.) i podejźrzon (Botrychium lunaria Sw.), „Rocznik Naukowo-Dydaktyczny Wyższej Szkoły Pedagogicznej w Krakowie” z. 80, Kraków, s. 165-171.

A. Spólnik, 1990, Nazwy polskich roślin do XVIII wieku, Prace Komisji Językoznawstwa PAN w Krakowie nr 58, Wrocław etc. 
SSSL - Indeks do Słownika stereotypów i symboli ludowych, t. II. Rośliny (nieopublikowany wydruk udostępniony mi uprzejmie przez prof. Annę Tyrpę za zgoda prof. Jerzego Bartmińskiego).

SSSL Zioła - Słownik stereotypów i symboli ludowych, koncepcja całości i redakcja: J. Bartmiński, zastępca redaktora: S. Niebrzegowska-Bartmińska, t. II: Rośliny, cz. 4: Zioła, Lublin 2019.

SStp - S. Urbańczyk (red.), 1953-2002, Słownik staropolski, t. I-XI, Wrocław.

J. Stanko, 1472, Antibolomenum Benedicti Parthi [rękopis przechowywany w Bibliotece Krakowskiej Kapituły Katedralnej, nr Ms 225].

SW - J. Karłowicz, A. Kryński, W. Niedźwiedzki, 1900-1927, Słownik języka polskiego, t. I-VIII, Warszawa (tzw. Słownik warszawski).

SWil - A. Zdanowicz et al., 1861, Słownik języka polskiego, t. I-II, wyd. M. Orgelbrand, Wilno (tzw. Słownik wileński).

Symb. - J. Rostafiński, 1900, Symbola ad historiam naturalem medii aevi..., t. I-II, Cracoviae.

Syreniusz 1613 - S. Syrenius, 1613, Zielnik herbarzem z ięzyka Łacińskiego zowia..., Kraków.

SZ - E. Szot-Radziszewska, 2005, Sekrety ziół. Wiedza ludowa, magia, obrzędy, leczenie, Warszawa.

K. Szcześniak, 2008, Świat roślin światem ludzi. Na pograniczu wschodniej i zachodniej Słowiańszczyzny, Gdańsk.

Šugar HBI - I. Šugar, 2008, Hrvatski biljni imenoslov. Nomenclator botanicus croaticus, Zagreb.

R. Tokarski, 1993, Słownictwo jako interpretacja świata [w:] J. Bartminski (red.), Encyklopedia kultury polskiej XX wieku, t. II: Współczesny język polski, Wrocław, s. 335-362.

M.A. Trotz, 1764, Nowy dykcjonarz, to jest mownik polsko-niemiecko-francuski..., Leipzig.

A. Tyrpa, 2001, Tabu w dialektach polskich, Bydgoszcz.

S. Udziela, 1891, Medycyna i przesady lecznicze ludu polskiego, Warszawa.

USK - Cz. Robotycki (red.), 1995, Układ słów kluczowych dla bazy danych o źródłach etnograficznych (kultura ludowa Karpat polskich), Kraków.

Vasmer ES - М. Фасмер, 1964-1973, Этимологический словарь русского языка. Перевод с нем. и дополнения О.Н. Трубачева, I-IV, Moskva.

J. Waniakowa, 2007, Mandragora and belladonna - the names of two magic plants, „Studia Linguistica Universitatis Iagellonicae Cracoviensis” 124, s. $161-173$.

J. Waniakowa, 2012, Polskie gwarowe nazwy dziko rosnacych roślin zielnych na tle słowiańskim. Zagadnienia ogólne, Kraków.

J. Waniakowa, 2016, Niedosłowność $w$ nazwach roślin [w:] M. Odelski, A. Knapik, P. Chruszczewski, W. Chłopicki (red.), Niedosłowność w języku, seria: Język a komunikacja, t. 37, Kraków, s. 413-425.

W. Weryho, 1888, $Z$ medycyny ludowej, „Wisła. Miesięcznik Geograficzno-Etnograficzny" t. II, Warszawa, s. 604-607.

A. Wierzbicka, 2009, Świat człowieka odzwierciedlony $w$ fitonimach [w:] I. Generowicz, E. Kaczmarska, I.M. Doliński (red.), Świat ukryty w słowach, czyli o znaczeniu gramatycznym, leksykalnym i etymologicznym, Warszawa, s. 415-425. 
ZDK - J. Rogala, R.M. Śnieciński (zebr. i oprac.), 2009, Zielnik dla każdego, czyli opis ziól wykorzystywanych $w$ leczeniu domowym wraz $z$ praktycznym zastosowaniem (napary, wywary i wyciagi zdrowotne), Ożarów Mazowiecki. ZL - A. Dziak, B. Kuźnicka, 1960, Zioła lecznicze, Warszawa.

\section{Dialectal names of plants as a reflection of dialect users' attitude towards the nature (historical and comparative approach)}

\section{Summary}

This text discusses Polish dialectal names of plants, which reflect the human attitude towards the world of flora. Therefore, the basic issue is the motivation behind plant names. These names are motivated by species characteristics. The motivations where the human attitude towards the nature are particularly visible have been taken into consideration. These are primarily medicinal properties and the attributed (positive or negative) magical properties, harmfulness of certain species, application and purpose in the homestead, and annoying negative characteristics. The relation between plant names and folk beliefs and legends are analysed, religious references are also made. The significant role of taboos and metaphors in the plant denomination process is emphasised in the discussions. The names are examined from the historical and comparative perspective, which is illustrated with examples.

Keywords: folk names of plants - semantic motivation - origin of plant names - metaphor - taboo

Trans. Monika Czarnecka 